\title{
The behavior of muzakki in paying zakat; phenomenological study of muzakki's experience in Semarang City
}

\author{
Siti Rohmawati ${ }^{1}$, Musahadi $^{2}$, Ali Murtadho ${ }^{3}$ \\ 1,2,3 Faculty of Islamic Economics and Business, Universitas Islam Negeri Walisongo, \\ Indonesia
}

\begin{abstract}
Purpose - This study aims to determine muzakki's behavior which is reviewed based on the theory of planned behavior, including attitudes towards behavior, subjective norms, and perceived behavioral control.

Method - This research used a qualitative research method, while the analytical approach used phenomenological analysis. This study utilized observation and interviews for collecting data. Informants were given a great space to tell their own experiences freely. The number of samples in the study was six informants, i.e., two people who work as civil servants, two people as entrepreneurs, and two people as farmers.
\end{abstract}

Result - Based on the phenomenon and its meaning regarding the behavior of muzakki in paying zakat, it can be concluded that 1) The attitude of the informants tends to comply with the obligation to issue zakat as a form of religious, social, economic, and psychological obedience 2) Informants have subjective beliefs regarding the behavior of paying zakat which is formed from normative beliefs, namely references that come from external and internal parties. 3) Perceptions of behavioral control of the informants.

Implication - This study can assist people and organizations in understanding the behavioral aspect of muzakki.

Originality - The originality of this research lies in the object under study, test analysis, and research location.

Keywords: theory of planned behavior, muzakki, zakat, qualitative, phenomenology, Semarang City, Indonesia 


\section{Introduction}

At the end of 2019, the potential for national zakat in Indonesia reached $233.84 \mathrm{~T}$. However, data in the field shows that the zakat funds collected in 2019 are projected to reach $7.05 \mathrm{~T}$. The fact that

JIEMB | 82 zakat potential inequality with the amount of zakat obtained indicates an imbalance between the compulsory zakat. With zakat managers. The minimum amount of zakat received compared to the potential for zakat is the influence of muzakki (a person who gives zakat) behavior to give zakat. These behaviors include attitudes through beliefs, subjective norms from the expectations of outsiders who influence muzakki, and other biases that support or hinder muzakki from issuing zakat (perceived control).

Efforts to manage zakat in Central Java, especially Semarang City, are still beyond the target of achievement. The potential for zakat in the city of Semarang is quite significant, reaching Rp. 150 billion. Still, in 2017 the income of zakat funds was 3 billion, then increased to 6 billion in 2018, while in 2019, it was able to collect zakat funds of 8.2 billion. The problems in society that cause the collection of zakat funds in the city of Semarang are still low, apparently due to a limited understanding of the meaning and essence of zakat. Lack of socialization from BAZ and LAZ is also one of the factors that cause muzakki not to pay zakat through amil zakat but is given directly to the surrounding mustahiqs. Unfortunately, some people pay zakat by distributing it now to those around them who feel less well off.

To improve zakat management, the city government of Semarang issued a Regional Regulation (Perda) of Semarang City Number 7 of 2009 concerning Zakat Management. However, the Perda, which has binding strength, does not seem to have worked as expected. The phenomenon of the gap between the magnitude of the potential for zakat and the amount of zakat obtained is interesting for further exploration of the behavior of muzakki in issuing zakat who are still reluctant or indifferent to their obligations. Based on this phenomenon, the questions that become the focus of this study are 1) How do muzakki pay zakat in Semarang, 2) How do muzakki refer to the behavior of paying zakat in Semarang, and 3) How do muzakki's perceived behavioral control issue zakat in the city of Semarang. 


\section{Literature review}

Bachmid (2012) stated that there is still a tiny amount of zakat collection due to the behavior of muzakki, who are still reluctant and do not care about their obligation to pay zakat. The BAZDA that was formed has not been able to be widely recognized by the public. Previous research conducted by Afiyana, Nugroho, and Fitrijanti (2019) found an imbalance between the potential and the realization of zakat collection due to a lack of trust from the public zakat management institutions so that more people channel their zakat directly to the mustahiq around them.

Further research by Merlinda, Burhan, and Ekawaty (2016) in "The determinants of Muslim Decision in Performing Commerce Zakat Payment: Case Study in Malang City, East Java Province" showed that the income and knowledge of muzakki could influence the decision of Muslims to pay zakat. According to these results, muzakki in paying zakat are due to the preference of muzakki in Malang to hand over their zakat to non-formal institutions or give it directly to recipients who are entitled to receive it. Informants who give zakat and do not know are more likely to use guidance or directions from prominent figures such as Kyai to who is entitled to their zakat.

Saad and Haniffa (2014), in their research entitled "Determinants of Zakat (Islamic tax) compliance behavior," used the theory of reasoned action from Ajzen and Fishebein. The study results reveal that the attitudes of muzakki and subject norms can support muzakki behavior in issuing zakat. Intention significantly influences the obedience behavior of muzakki in administering zakat. Reasoned action can effectively explain the obedience behavior of paying zakat. Improved communication through direct interaction or regular meetings affects the intention to pay zakat.

Based on the description above, this study focuses and aims to reveal the obligatory behavior of zakat issuing zakat, including first, the attitude of muzakki, which considers conducting behavior through the beliefs obtained whether it causes benefits or losses for themselves and their social environment. Second, subjective norms are predicted from the references and expectations of the people around them and leaders who motivate certain behaviors. Third, the perception of behavior control is a condition where supporting and 
inhibiting factors become a consideration for deciding to take specific actions and behaviors.

\section{Methodology}

This research utilizes a qualitative approach due to the focus and objectives of the study. This research aims to reveal the obligatory behavior of zakat. Zakat's behavior includes aspects of attitudes obtained from beliefs about the obligation of zakat, references and expectations from people around which influence muzakki, and perceptions of behavioral control that can support or even hinder muzakki issuing zakat. The qualitative paradigm or positivist paradigm was chosen in this study uses a phenomenological analysis. A phenomenology can explain how to socially construct objects and knowledge from events that are encountered in everyday life.

This study was conducted to explore and reveal the informants' experiences as it is known that qualitative research, informants, or samples are more directed towards theoretical generalizations. This study's sources of data are primary data obtained directly from observations and interviews with six informants, namely two civil servant informants, two entrepreneur informants, and two farmer informants. The main reason for determining informants is the consistency level of muzakki and differences in views in fulfilling their obligation to pay zakat. Therefore, of course the intention of the muzakki to behave in paying zakat has different ideas or particular reasons. So the method of determining the informants used was purposive sampling.

The technique of collecting data is through the interview process or in-depth interview. At the same time, the data analysis technique uses data analysis with phenomenological studies referring to the qualitative research of Miles and Huberman, which connects the interactive and comparative analysis models.

\section{Results and discussion}

Based on the descriptions and summary schemes formulated from the experiences of each informant, several syntheses can be produced. In simple terms, the summary for each informant is shown in the following figure. 


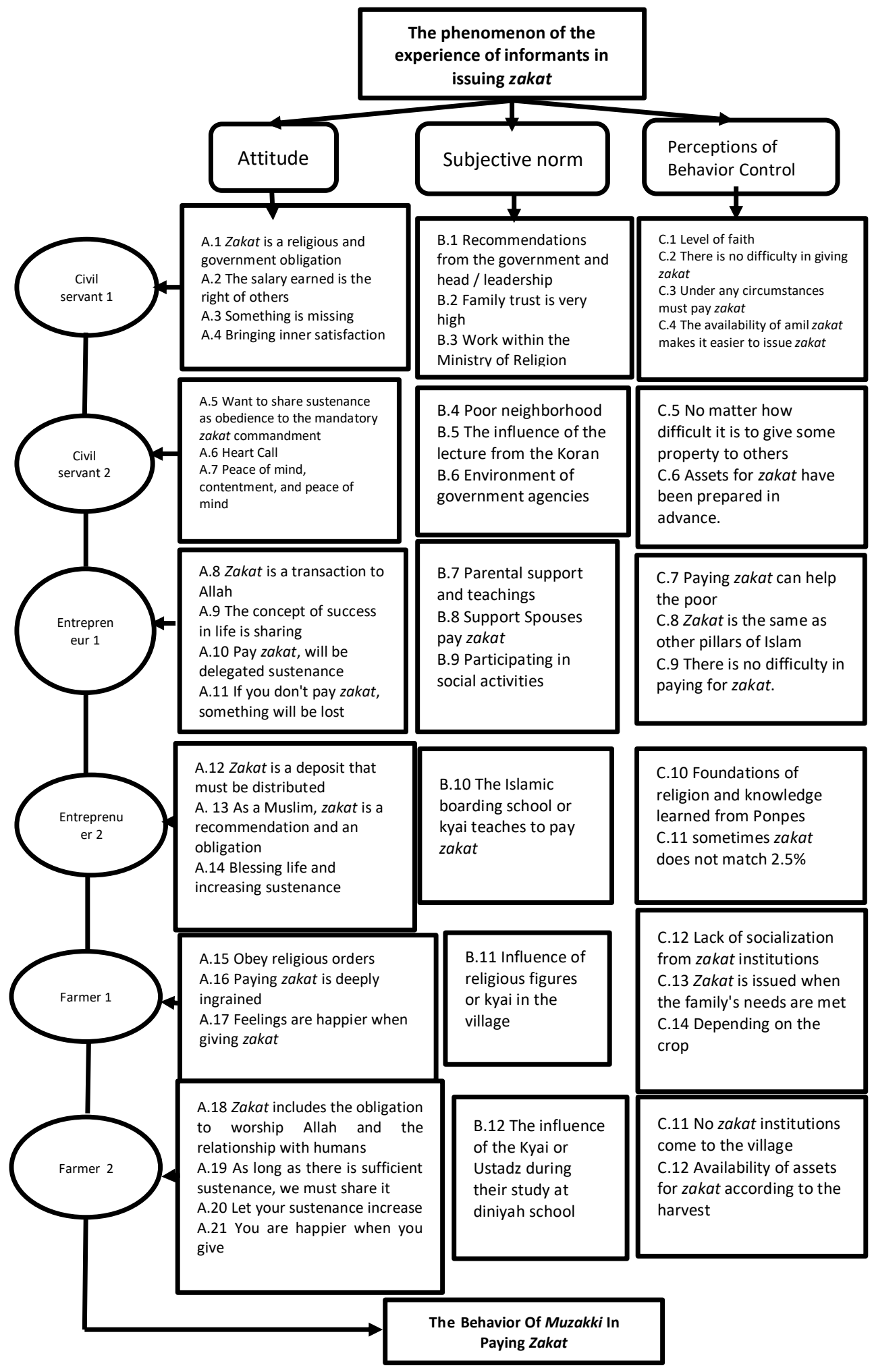




\section{Muzakkis Attitude Issues Zakat}

The research results on the attitudes of muzakki in issuing zakat based on the informants' experiences show that the factor of submission to Allah's orders is an important part. However, there are differences in beliefs between the civil servant 1 informant and the other five informants. The idea that shapes the attitude of paying zakat is a religious obligation and an obligation as a society that obeys government orders. With muzakki is a person or business entity that is obliged to pay zakat. On the other hand, the government regulation states that paying zakat is an obligation for every able Muslim to comply with Islamic law.

This finding contributes that the issuance of zakat is influenced by the factor of submission to religious orders and social factors. The social factors is that the informants have a strong desire to share and realize benefits for other humans. In addition, the form that the informants wanted to achieve on property ownership was to obtain wealth blessings and increase sustenance and obtain business permanence (entrepreneur informant 1 and entrepreneur 2). The impact of paying zakat also consistently creates peace of mind and inner satisfaction for informants. The research results regarding the informants' attitudes in this study also construct Monzer Khaf's thoughts regarding the concept of final spending. According to him, for the muzakki group, final spending is to obtain maximum satisfaction based on the amount of wealth and level of income. Thus, the satisfaction will be greater when the community is in good economic conditions. The reason is, muzakki will get this satisfaction when the income they earn can meet their needs and carry out their obligation to pay zakat. In addition, the evaluation of attitudes towards the behavior of informants in issuing zakat is that they feel that something is missing and uncomfortable (civil servant 1 informant and Entrepreneur informants).

\section{Muzakki's reference to issue zakat}

The phenomenon regarding muzakki issuing zakat constructs Ajzen's planned behavior theory that environmental factors will directly influence muzakki's behavior in issuing zakat. In his research, it was found that the support of parents and spouses greatly influences the issuance of zakat. In addition, family trust in muzakki who pays out zakat is very high. On the other hand, the 
influence of the advice of the kyai/ustad (religious preacher/leader) involved in the socialization of issuing zakat.

Subjective norms are formed from people who are considered influential (reference significant others) and also the behavior of muzakki in issuing zakat. Reference of this case consists of internal references and external references. Internal references to muzakki behavior are based on self-will and internal intentions. In addition, internal references are also obtained by muzakki from the habits of parents and support from their husbands (entrepreneur informant 1). Meanwhile, external references are received by muzakki from the workplace environment (civil servant 1 informant) and environmental factors from Islamic boarding schools (entrepreneur informant 2). In addition, external references to muzakki behavior come from kyai / ustadz / mubaligh's advice and gave lectures on the obligation to pay zakat (felt by the PNS informant 2, entrepreneur informant 2, farmer informant 1 and farmer informant 2).

\section{Perception Control of Muzakkis Behavior Issues Zakat}

The phenomenon that supports or hinders muzakki from issuing zakat leading to different interpretations of perceived behavioral control. The perception strengthens intention of the muzakki to pay zakat is based on one of the pillars of Islam. Civil servant 1 informant, Civil servant 2 informant stated that the obligation of zakat is the same as the obligation to pray and has the same position as the other pillars of Islam. This behavior is seen as vital so that the intention of the muzakki to pay zakat is powerful. The entrepreneur informant 2 added that his knowledge during his time as a student at the Islamic boarding school was very supportive because the kyai always taught him to pay zakat. In the end, the value of pay zakat is embedded in him.

One of the goals of paying zakat is to help the mustahiq economy. For Civil servant informants, Civil servant 2 informants, and entrepreneur 1 informants, every zakat issued is expected to be able to contribute to the economy of those in need. Under any circumstances, zakat is still an obligation. This perception of belief gives birth to a solid intention to keep giving zakat. Meanwhile, the intention of muzakki behavior decreases when the results of the income obtained are uncertain (entrepreneur informant2, farmer informant 1 and farmer informant 2). This behavior is seen as reducing the intention to pay zakat-in addition, paying zakat if it is Journal of Islamic Economics, Management, and Business-Vol 2. No.2 (2020) 
sufficient to meet the family's needs. In the end this perception also discourages the intention to pay zakat. (farmer informant 1).

\section{Conclusion}

Based on the descriptions and interpretations of various phenomena related to attitudes, references, and perceptions of behavioral control by informants, several conclusions can be drawn. The attitude of issuing zakat is a form of values that must be manifested from submitting to giving zakat. There are four aspect, the most important one is a form of obedience to Allah's orders and the government for civil servant 1 . Besides a form of compliance, there are also social values (in the form of mutual variety to others) and economic value (blessing wealth and value for tranquility and inner satisfaction or moral values).

The phenomenon of the reference to muzakki issuing zakat shows different meanings-first, references from the support of parents and husbands influencing entrepreneur 1 informants to give zakat. Second, for civil servant 1, references to the workplace environment became the most significant effect. Third, for entrepreneur 2, the environmental factors from Islamic boarding schools became the main factor. In addition, the cleric/ustadzl mubaligh who issued zakat also influenced the civil servant 2 , the entrepreneur informant 2, the farmer informant 1 and the farmer informant 2.

The supporting factors of muzakki issuing zakat provide different results for informants of civil servant 1 , civil servant 2 , and Entrepreneurs 1. For the latter, zakat is also a medium to channel their income; however, for entrepreneur informants 2, farmer informants 1 and farmer informants 2, zakat is issued if there are excess assets. Furthermore, regarding behavior control, if the behavior is considered good, it strengthens or supports the muzakki to give zakat; however, if this behavior is seen as weakening or hindering, the intention to pay zakat will also decrease.

\section{References}

Afiyana, I. F., Nugroho, L., Fitrijanti, T., \& Sukmadilaga, C. (2019). Tantangan pengelolaan dana zakat di indonesia dan literasi zakat. Akuntabel, 16(2), 222-229. 
Bachmid, G. (2012). Perilaku muzakki dalam membayar zakat mal (Studi fenomenologi pengalaman muzakki di Kota Kendari). Jurnal Aplikasi Manajemen, 10(2), 425-436.

Baznas.semarangkota.go.id, accessed on 15/01/2020.

Merlinda, S., Burhan, U., \& Ekawaty, M. (2016). The determinant of moslem's decision in performing commerce zakat payment: Case study in Malang city, East Java Province. International Journal of Social and Local Economic Governance, 2(1), 59-68.

Outlook BAZ Nasional 2020

Saad, R. A. J., \& Haniffa, R. (2014). Determinants of zakah (Islamic tax) compliance behavior. Journal of Islamic Accounting and Business Research. 
Siti Rohmawati, Musahadi, \& Ali Murtadho

JIEMB | 90

Journal of Islamic Economics, Management, and Business-Vol 2. No.2 (2020) 